\title{
Banning Loose Cigarettes and Other Tobacco Products in India: A Policy Analysis
}

\author{
Shivam Kapoor ${ }^{1 *}$, Rashmi Mehra ${ }^{2}$, Amit Yadav ${ }^{1}$, Pranay Lal $^{1}$, Rana J Singh $^{1}$
}

\begin{abstract}
Background: Sale of single cigarettes (also known as singles or loosies) is a key driver for early initiation of smoking and is a leading contributor to the smoking epidemic in India. Sale of singles additionally deter implementation of tobacco control strategies of pictorial health warnings including plain packaging and defeat effective taxation and promote illicit trade. We review India's tobacco control policy responses towards banning singles and other products sold as loose tobacco and identify opportunities for future policy intervention especially in the context of the ongoing COVID-19 pandemic. Methods: Existing national and sub-national policy documents were analyzed for their content since the inception of the tobacco control laws in the country. Results: There are no effective provisions at national level to ban loose tobacco products in India. However, the implementation of multiple legislative and regulatory measures (Acts/circulars/letters/notifications/orders/court judgements) in 16 Indian states and jurisdictions provide sufficient legal framework to substantiate its complete ban pan India. While the majority of state governments have adopted state level measures, Rajasthan had issued specific directive to all the 33 districts banning loose cigarettes and other tobacco products. Himachal Pradesh introduced the most unique and comprehensive legislation, for banning the sale of cigarettes and beedis (Dated November 7, 2016). The most recent notification in the state of Maharashtra (September 24, 2020) is the first to leverage powers using a mix of national and state legislations including the legislation addressing the rapidly emerging challenge of managing COVID-19. Conclusion: A robust national policy which supports strong provision to deter tobacco companies, their distribution network and vendors from selling singles or loose tobacco products is urgently needed. Such policy should be backed by cautionary messaging for consumers as well. Eliminating singles and loose tobacco sale will help in blunting tobacco use prevalence besides curbing spread of infectious diseases like COVID-19 pandemic.
\end{abstract}

Keywords: COVID-19- loose cigarettes- policy- tobacco epidemic- single stick

Asian Pac J Cancer Prev, 22, Progress of Tobacco Control in the South-East Asia Region Suppl, 51-57

\section{Introduction}

In the landmark report on tobacco control in India, sale of single cigarettes or singles or loosies is identified as the 'driver of the smoking epidemic' in India (Reddy and Gupta, 2004). According to the Global Adult Tobacco Survey (2009-2010), 57\% of smokers purchased loose cigarettes. This situation has worsened since then with two-thirds of cigarette smokers, one-sixth of bidi smokers and one-fourth of smokeless tobacco users found to purchase tobacco in an unpackaged form (GATS-2, 2016-2017).

This is because singles make smoking habit accessible and affordable for smokers in India who might not be able to afford a complete pack of cigarettes (Lal et al., 2015). Multiple studies across the globe have suggested that poor education and income status have been consistently associated with the purchase behaviour of loose cigarettes highlighting the inducement to tobacco use by ease of availability and affordability of loose tobacco products (de Ojeda et al., 2012; Hall et al., 2015; Singh et al., 2017).

Furthermore, the single cigarette market nullifies on-going tobacco control efforts including pictorial warning and effective taxation, thereby making it one of the most powerful tools for the tobacco industry (Hall et al., 2015; Lal et al., 2015). Soliciting loose cigarettes and other tobacco products violates multiple central legislations like the Central Excise Act, 1944 (Central Board of Indirect Taxes and Customs, 1944) which taxes 'sin goods' on pro rata basis, and the Legal Metrology Act, 2009 (Department of Consumer Affairs, 2010) which specifies that no packaged product can be broken and its constituents sold individually. Article 16 of the WHO's Framework Convention on Tobacco Control (FCTC) prescribes comprehensive policy measures and proven strategies to eradicate the sale of loose cigarettes or 'singles' and other tobacco products (WHO, 2003). While other South-Asian countries including Cambodia, 
Myanmar and Nepal have adopted strict policies to keep singles in check, India being the second largest tobacco consumer in the world is yet to adopt checks to curb sale of loosies (Tobacco Control Laws, 2021). Although India enacted the Cigarettes and Other Tobacco Products Act (COTPA) in 2003 (COTPA, 2003), much before ratification of FCTC in 2004, in order to discourage the use of tobacco, impose progressive restrictions, yet it does not specifically restrict the sale of singles or open sale of unlicensed locally manufactured tobacco products. Section 7 under COTPA clearly restricts trade, commerce, production, supply and distribution of cigarettes and other tobacco products without a specified Pictorial Health Warning (PHW) on the package (COTPA, 2003). There is no clear-cut mention for banning the loose cigarette and other tobacco products anywhere in the principal act (COTPA, 2003), except for the recently proposed amendment sub-section (2) of section (7) in the COTPA (Amendment) Bill 2020 which adds in the Principal Act, inter alia: "Provided that the trade and commerce in cigarette or any other tobacco product shall be in sealed, intact and original packaging" (COTPA Amendment Bill, 2020).

Given the serious consequences of single cigarette sales and the smoking epidemic (nearly 100 million smokers), this single point of inflection where the smoking addiction gets initiated remains unaddressed. The COVID-19 pandemic, despite being an unprecedented challenge (Chaudhary et al., 2020; The Lancet, 2020) (Figure 1), serves as an opportune time to bring this issue to the forefront considering the growing concern around increased vulnerability among tobacco users to COVID-19 infection and disease progression (Gallus et al., 2020; Simons et al., 2020). While many Indians continue to suffer from COVID-19, the continued availability of single sticks in the Indian market places make smoking (a potential and contributory risk factor for COVID-19) an affordable addiction and a simultaneous revenue loss due to limited implementation of taxation of single cigarettes (Reddy and Gupta, 2004; Lal et al., 2015; von Lampe et al., 2018; Kashyap et al., 2020; Kesar et al., 2021). This triple-tiered epidemic epiphany urges the policymakers to further the much-needed policy shift.

Therefore, to understand the existing policy interventions brought about in India, both at national and sub-national level, the present policy review and analysis was undertaken. The aim of the present policy analysis was to examine India's position on banning loose cigarettes, beedis (India's indigenous hand-rolled cigarillos) and other tobacco products as an effective tobacco control measure.

\section{Materials and Methods}

As endorsed by Collins (2005), the present policy analysis includes publicly available policy documents pertaining to the ban on loose cigarettes and other tobacco products in India. These included policy documents both from national and sub-national levels (states/UTs and districts) since the enactment of COTPA, 2003 and up to June 28, 2021.
Drawing from the varied and broad scope employed in the methodologies for public policy analysis, and with the backdrop of our experiences framed by existing theories and models (Walt and Gilson, 1994; Collins, 2005; Collins and Fauser, 2005; Patton et al., 2013), we undertook a descriptive policy analysis to assess, examine and analyse the status quo with a scope of improvement in the present context of the pandemic situation.

\section{Results}

Overall, one national-level and 16 state/UTs-level documents in varying formats (Act/circular/letters/ notifications/orders/court judgements) were included and analysed for their contents.

\section{National level policy response}

We analysed The Legal Metrology Act, 2009 (Department of Consumer Affairs, 2010) that establishes and enforces standards of weights and measures, regulates trade and commerce in weights, measures and other goods which are sold or distributed by weight, measure or number. Section 18 under this Act details the standardisation of packaged commodities, while Section 30 penalizes the seller, buyer or any person for transactions in contravention of standard weight or measure with a fine which may extend to ten thousand rupees, and, for the second or subsequent offence, with imprisonment for a term which may extend to one year, or with fine, or with both (Department of Consumer Affairs, 2010). A slight exception has been made for Bidi manufacturers under The Legal Metrology (Packaged Commodities) Rules, 2011 (Department of Consumer Affairs, 2011) i.e. "(i) no declaration as to the retail sale price; and (ii) the month and year in which the commodity is manufactured or pre-packed shall be required to be made on any package containing bidi." (Table 1). No such exception is mentioned for cigarettes or other tobacco products.

\section{State-level policy response}

On May 3, 2014, the state of Uttarakhand became the first to notify a ban on the sale of loose cigarettes but did not specify any other tobacco products along with no mention of a specific punishment or penalty on violation. This state-level ban was time-bound (six months) and imposed on the basis of a writ petition that was passed by the Honourable High Court of Uttarakhand (Case, 2014). This paved the way for a state-level notification later on November 29,2014. The policy response by states to ban loose tobacco products has been disparate and mainly consider the provisions under the Section 7 or Sub-section 2 of the Section 7 under COTPA, 2003. On November 4, 2015, the state of Himachal Pradesh notified a complete ban on sale of single sticks/loose cigarette(s) and beedi(s). A year later (November 7, 2016), 'The Himachal Pradesh Prohibition of Sale of Loose Cigarettes and Beedies and Regulation of Retail Business of Cigarettes and Other Tobacco Products Act, 2016' followed (Act No. 17 of 2016). All offences under this act are compoundable and to be tried summarily in accordance with the Code of Criminal Procedure, 1973. Any person that sells, offers for 


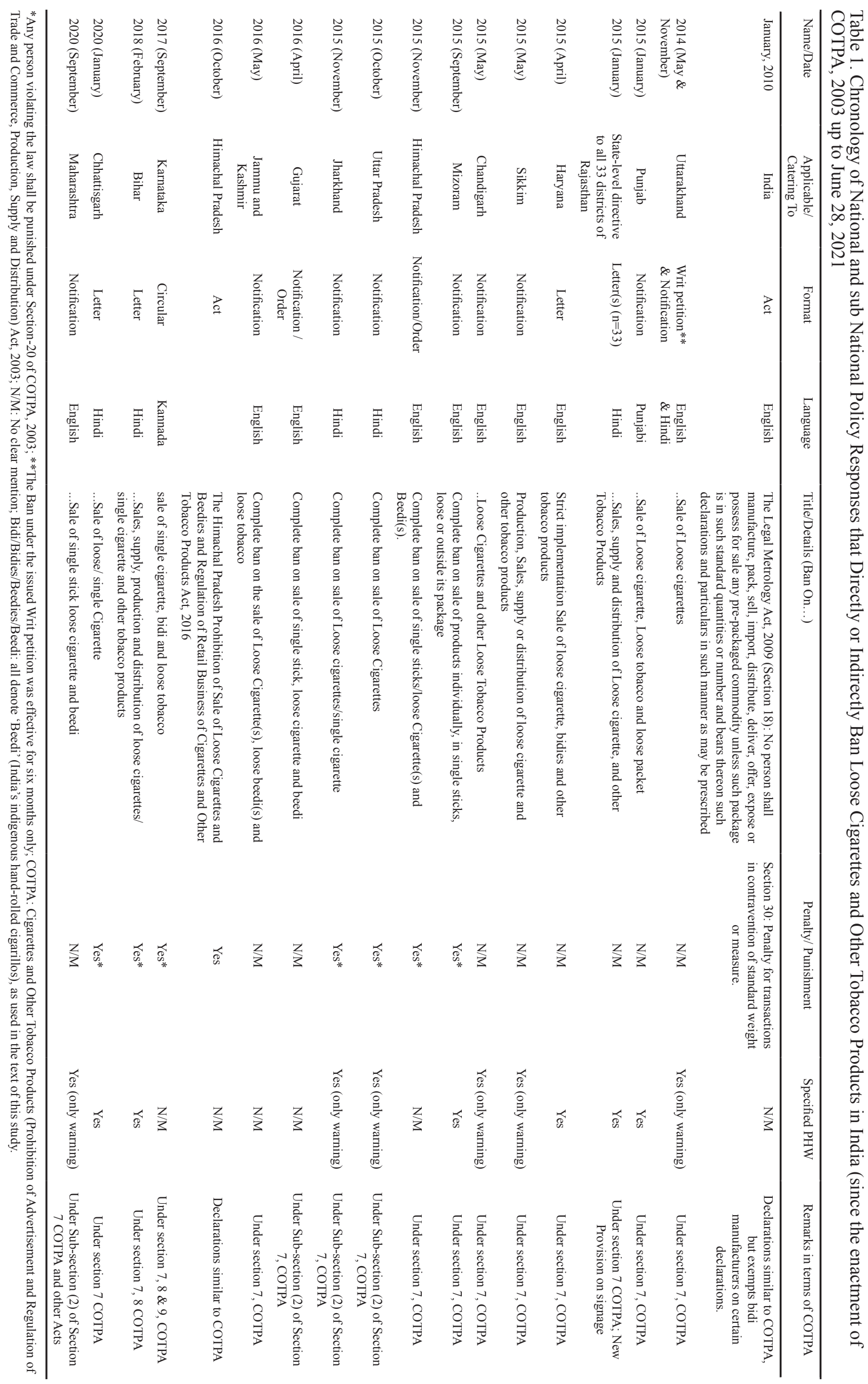


sale, or permits sale of loose cigarettes or beedis within Himachal is liable to a fine of ten thousand rupees for the first offence and with fine of fifteen thousand rupees for the second and subsequent offence. The government of Bihar, Chhattisgarh, Jharkhand, Karnataka, Mizoram and Uttar Pradesh penalizes the offender under Section-20 of COTPA, 2003 (Table 1).

The Maharashtra government, with the most recent notification (September 24, 2020), uses an ensemble of laws-The Epidemic Diseases Act (1897), the Indian Penal Code (1860), the Mumbai Police Act (1951), Criminal Procedure Code (1973), National Disaster Management Act (2005), the Cigarette and Other Products Act 2003, Notification No. GSR-739 (E) (September 24, 2015) and the State-wise total ban on spitting and smoking in public places (May 29, 2015). As a result, it becomes the first and only state to address the rapidly emerging challenge of managing COVID-19 transmission and disease progression. However, this effort is limited to cigarettes and beedis only and does not apply to other tobacco products.

Overall, the contents of the analysed policy documents ranged from a brief paragraph (Chandigarh) to a detailed 20-page writ petition (Uttarakhand). Majority of the state/ UT level documents are drafted in English (9 out of 16) with the rest in other languages (Hindi=5, Punjabi and Kannada=1) (Table 1).

Overall, the writ petition (Uttarakhand) is the most elaborate document however, it bans cigarettes only. It takes into consideration the historical background of the Cigarettes Act, 1975 and COTPA, 2003 (Case, 2014). Many other issues such as maximum permissible quantity of nicotine and tar in cigarettes, patterns of tobacco cultivation, observance of any cigarette manufacturing unit and data pertaining to cigarette/ tobacco related deaths within the State of Uttarakhand have been discussed (Case, 2014). The Writ negates the previous judgement (para 11 and 29, Writ Petition No. 37 of 2014) claiming "if a cigarette is not bearing the specified warning, the same should be sold with the label, which must bear the specified warning"

The Additional Mission Director, National Health Mission (State Tobacco Control Cell), Rajasthan has addressed to all the 33 districts in the form of letters (dated January 23, 2015). There is a provision on signage i.e. the main entrance of shop/kiosk must have a signage stating "Loose cigarettes aren't sold here". The official letter issued for the state of Bihar mentions the provision of pictorial health warning under both Section 7 and 8 of COTPA.

\section{Discussion}

In the year 2009, to prevent the sale of "kiddy packs" i.e. cigarettes individually or in small packets, only $57 \%$ parties to the FCTC (67 countries) had policies (World Health Organization, 2009). By 2018, two-third (67\%) of the parties $(n=181)$ had policies in place (World Health Organization, 2018). Even after completing 18 years as a signatory to the FCTC, there is no uniform national policy regarding banning loose tobacco products in India. The passing mention in the recently proposed COTPA Amendment Bill, 2020 might also need to specify: (i) the minimum allowed number of cigarettes and beedis in a packet and pack size for SLT, (ii) clear mention of punishment, at least similar to what is mentioned in 'The

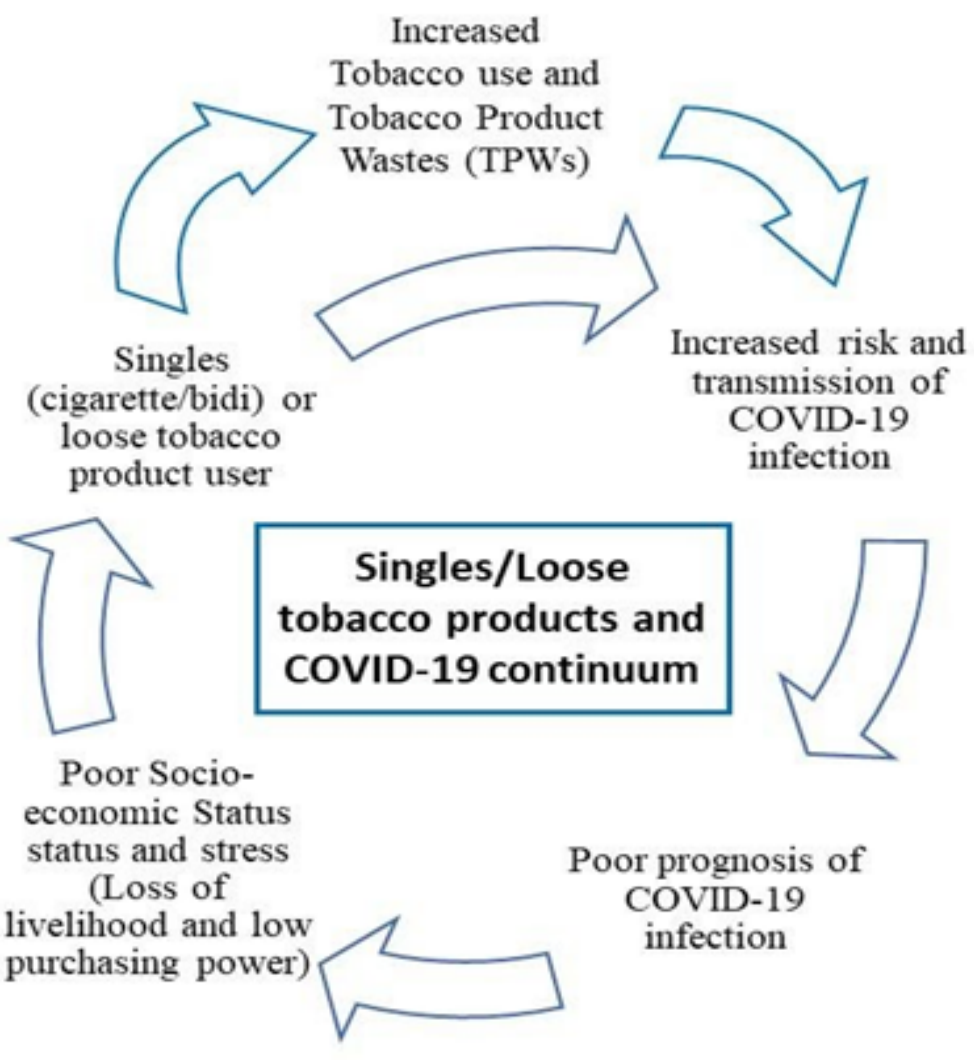

Figure 1. The Singles/Loose Tobacco Products and COVID-19 Continuum 
Himachal Act' (Act No. 17 of 2016) and (iii) provision of signage, as prescribed under the State-level directive to all 33 districts issued by the Government of Rajasthan (Government of Rajasthan, 2015). This paper appeals to the Government of India to eliminate "kiddy packs" by honoring its FCTC commitment under the proposed revisions in the existing law.

A number of studies have reiterated that tobacco has the potential to act as a risk factor for severe COVID-19 infection and death (van Zyl-Smit et al., 2020; Cattaruzza et al., 2020; Reddy et al., 2021; Umnuaypornlert et al., 2021). To the best of our knowledge, the present study is the first to voice an early call for action to curb the potential menace of loose tobacco products that is worsening the tobacco epidemic especially during the COVID-19 pandemic. We found that in the absence of a national policy, India has employed a "bottom-up" approach where states like Rajasthan have initiated State-level directive to all 33 districts to ban sale of loose tobacco while several others have implemented state level actions including a specific legislation on the matter by the state of Himachal.

The faltered ban implementation and low enforcement in several Indian states with existing ban on loose tobacco products (Sahani, 2015; Jha, 2016), along with low vendor awareness regarding the ban (Ravishankar et al., 2016), makes it an even bigger challenge. Clearly, this is half the battle won (Kumar and Chauhan, 2018). While Industry trade union has not opposed the existing ban in the state of Himachal Pradesh, Tobacco Sellers Association in Uttar Pradesh has strongly protested against the ban imposed on sale of loose cigarettes by the state government (Madan, 2015). However, the silver lining is that $59 \%$ young Indians strongly believe that banning singles would reduce the prevalence of smokers in the country, as reported in a national poll by Inshorts and Ipsos (Express Web Desk, 2017).

Additionally, as an endgame that might necessitate supply reduction, Ioannidis and Jha (2021) propose drastic tobacco control policy measures during COVID-19 to eliminate the tobacco industry. On similar lines, India has made exemplary progress during the pandemic, by prohibiting the sale and use of SLT and spitting through a combination of laws and rapid enforcement action in 23 states and 187 districts from 11 states. (Lal et al., 2020)

Despite best efforts, the present study does present the inherent limitation of being a descriptive crosssectional policy analysis with no concurrent monitoring of the implementation within each state. The present policy analysis found a limited number of policy level changes in response to the looming tobacco epidemic in the backdrop of the on-going pandemic. As a next step, a detailed policy triangulation must be conducted to examine policy content, context, actors and processes in a conceptual framework followed by prescriptive policy analysis (Patton et al., 2016).

The present paper highlights the developments related to banning singles/loose tobacco products in India. There has been significant but sporadic progress at sub-national level with policy level changes potentially impacting less than $50 \%$ of the Indian adult population (16 Indian states/ Union territories). Furthermore, sale of single cigarettes also results in loss of a sizable portion of revenue as the Government does not consider the full retail price at which single cigarettes are sold. Policy shift including a nationwide ban on singles/loose tobacco products via the amendment in the existing law would serve as a two-pronged response on the two leading public health concerns of the world- Tobacco and COVID-19 pandemic.

\section{Author Contribution Statement}

The authors confirm contribution to the paper as follows: study conception and design: SK and RM; data collection: SK; analysis and interpretation of results: SK; draft manuscript preparation: SK, RM, AY, PL, RJS. All authors reviewed the results and approved the final version of the manuscript.

\section{Acknowledgements}

SK, AY, PL and RJS thank Bloomberg Initiative to Reduce Tobacco Use for supporting the Tobacco Control Unit at The Union South-East Asia Office, New Delhi. SK, AY, PL and RJS also acknowledge the contribution of The Union South-East Asia Office' partner organisations for their support in gathering sub-national policy level documents: Balajee Sewa Santhan (BSS), Uttarakhand; Faith Foundation, Gujarat; Generation Saviour Association (GSA), Punjab; Marathwada Gramin Vikas Sanstha (MGVS), Maharashtra; Shikshit Rojgar Kendra Prabandhak Samiti (SRKPS), Rajasthan; Socio Economic and Educational Development Society (SEEDS), Bihar and Jharkhand; State Tobacco Control Cell, Chhattisgarh; State Tobacco Control Cell, Jammu and Kashmir; State Tobacco Control Cell, Karnataka; State Tobacco Control Cell, Mizoram; State Tobacco Control Cell, Himachal Pradesh; State Tobacco Control Cell, Sikkim; Uttar Pradesh Voluntary Health Association (UPVHA).

The publishing cost was provided by WHO office in South-East Asia.

\section{References}

Case (2014). Dharmendra Kansal (petitioner) Versus Union of India (UOI) and Others (respondents). In the High Court of Uttarakhand At Nainital. Writ Petition (PIL) No. 37 of 2014. Dated June 3, 2014.

Cattaruzza MS, Zagà V, Gallus S, D'Argenio P, Gorini G (2020). Tobacco smoking and COVID-19 pandemic: old and new issues. A summary of the evidence from the scientific literature. Acta Bio Medica: Atenei Parmensi, 91, 106.

Central Board of Indirect Taxes and Customs (1944). Department of Revenue, Ministry of Finance, Government of India. The Central Excise Act, 1944. Act No. 1 of 1944, dated February 24, 1944.

Chaudhary M, Sodani PR, Das S (2020). Effect of COVID-19 on Economy in India: Some Reflections for Policy and Programme. J Health Manage, 22, 169-80.

Collins JA, Fauser BC (2005). Balancing the strengths of systematic and narrative reviews. Hum Reprod Update, 


\section{1, 103-4}

Collins T (2005). Health policy analysis: a simple tool for policy makers. Public Health, 119, 192-6.

de Ojeda A, Barnoya J, Thrasher JF (2012). Availability and costs of single cigarettes in Guatemala. Nicotine Tob Res, 15, 83-7.

Department of Medical Health and Family Welfare (Tobacco Control and IRC), Rajasthan (2015). Loose Cigarette Ban DO Letters, Sales, supply and distribution of Loose cigarette, and other Tobacco Products. Letters (Hindi), dated January 23, 2015.

Express Web Desk (2017). The Indian Express, New Delhi (online). 59 per cent Indians believe ban on sale of loose cigarettes will check smoking: Survey. Editorial, dated May 31, 2017.

Gallus S, Lugo A, Gorini G (2020). No double-edged sword and no doubt about the relation between smoking and COVID-19 severity. Eur J Intern Med, 77, 33-5.

Government of Himachal Pradesh (Act No. 17 of 2016). The Himachal Pradesh Prohibition Of Sale Of Loose Cigarettes And Beedies And Regulation Of Retail Business Of Cigarettes And Other Tobacco Products Act, 2016.

Government of Maharashtra (2020). Public Health Department. Complete ban on the sale of single stick loose cigarette and beedi. Notification, dated September 24, 2020.

Hall MG, Fleischer NL, Reynales-Shigematsu LM, ArilloSantillán E, Thrasher JF (2015). Increasing availability and consumption of single cigarettes: trends and implications for smoking cessation from the ITC Mexico Survey. Tob Control, 24, 64-70.

Ioannidis JP, Jha P (2021). Does the COVID-19 pandemic provide an opportunity to eliminate the tobacco industry? Lancet Global Health, 9, 12-13.

Jha S (2016). Ban on sale of loose cigarettes goes up in smoke in Kanpur. The Times of India, Kanpur (online). Editorial, dated February 26, 2016.

Kashyap VK, Dhasmana A, Massey A, et al (2020). Smoking and COVID-19: Adding Fuel to the Flame. Int $J$ Mol Sci, 21, 6581 .

Kesar S, Abraham R, Lahoti R, Nath P, Basole A (2021). Pandemic, informality, and vulnerability: impact of COVID-19 on livelihoods in India. Canadian Journal of Development Studies/Revue canadienne d'études du développement, 2021, 1-20.

Kumar R, Chauhan G (2018). Banning loose cigarette sale-a bold supply side measure by State Government of Himachal Pradesh in India to decrease tobacco use. Tob Induced Dis, 16, 606 .

Lal P, Kumar R, Ray S, et al (2015). The single cigarette economy in India-a Back of the Envelope Survey to Estimate its Magnitude. Asian Pac J Cancer Prev, 16, 5579-82.

Lal P, Mishra D, Singh RJ (2020). A "Bottom-up approach" to introduce ban on tobacco products to prevent spitting during COVID-19: An early review of progress made and challenges. Int J Noncommunicable Dis, 5, 138.

Madan (2015). Himachal bans sale of loose cigarettes to dissuade youngsters from smoking. Himachal Watcher, Himachal Pradesh (online). Editorial, dated November 5, 2015.

Ministry of Health and Family Welfare (Tobacco Control Division), Government of India (2020). The Cigarettes and Other Tobacco Products (prohibition of advertisement and regulation of trade and commerce, production, supply and distribution) (Amendment) Bill, 2020 [Draft].

Ministry of Health and Family Welfare, Government of India (2003). Cigarettes and other tobacco products (prohibition of advertisement and regulation of trade and commerce, production, supply and distribution) Act, 2003, New Delhi:
India.

Ministry of Health and Family Welfare; Government of India (2010). Global Adult Tobacco Survey; GATS India- 20092010. International Institute for Population Sciences.

Ministry of Health and Family Welfare, Government of India (2017). Global Adult Tobacco Survey 2016-2017. International Institute for Population Sciences.

Obore N, Kawuki J, Guan J, Papabathini SS, Wang L (2020). Association between indoor air pollution, tobacco smoke and tuberculosis: an updated systematic review and metaanalysis. Public Health, 187, 24-35.

Pal R, Yadav U (2020). COVID-19 pandemic in India: present scenario and a steep climb ahead. J Prim Care Commun Health, 11, 2150132720939402.

Patton CV, Sawicki DS, Clark JJ (2016). Basic methods of policy analysis and planning, 3rd edition. In. The Policy Analysis Process. Routledge, Taylor and Francis Group, New York, USA, pp 22-4.

Ranjan R, Sharma A, Verma MK (2021). Characterization of the Second Wave of COVID-19 in India. medRxiv, pp 1-10.

Ravishankar TL, Chandra S, Tirth A, Tandon V, Ain TS (2016). Knowledge, attitude and practice of retail tobacco vendors and school personnel on Indian tobacco control laws (COTPA) in Moradabad City, India. Int J Contemp Med Res, 3, 3365-9.

Reddy KS, Gupta PC (2004). Tobacco control in India. New Delhi: Ministry of health and family welfare, Government of India, pp 43-7.

Reddy RK, Charles WN, Sklavounos A, et al (2021). The effect of smoking on COVID-19 severity: A systematic review and meta-analysis. J Med Virol, 93, 1045-56.

Sahani NS (2015). Tobacco ban orders in Uttarakhand go up in smoke. Hindustan Times, Dehradun News (online). Editorial, dated October 05, 2015.

Simons D, Shahab L, Brown J, Perski O (2021). The association of smoking status with SARS-CoV-2 infection, hospitalization and mortality from COVID-19: a living rapid evidence review with Bayesian meta-analyses (version 7). Addiction, 116, 1319-68.

Singh M, Dogra V, Kumar R, Kumar AM (2017). 'Loose' cigarettes association with intensity of smoking: A secondary data analysis from Global Adult Tobacco Survey, India, 2009-10. J Sci Soc, 44, 26.

Smoke-Free Uttarakhand (2014). Circulars and Orders. Government of Uttarakhand, Ban on loose cigarette. Notification, dated November 29, 2014.

The Lancet (2020). Redefining vulnerability in the era of COVID-19. Lancet (London, England), 395 (10230), 1089. Ministry of Consumer Affairs, Food and Public Distribution (Department of Consumer Affairs, 2011). The Legal Metrology (Packaged Commodities) Rules, 2011. Notification, dated March 7, 2011. Department of Consumer Affairs, 2010. The Legal Metrology Act, 2009. Act No. 1 of 2010, dated January 13, 2010.

Tobacco Control Laws (2021). Comparing sales restrictions among countries in South East Asia. https://www. tobaccocontrollaws.org/legislation/finder/\#_sales_ restrictions

Umnuaypornlert A, Kanchanasurakit S, Lucero-Prisno DEI, Saokaew S (2021). Smoking and risk of negative outcomes among COVID-19 patients: A systematic review and meta-analysis. Tob Induced Dis, 19.

Van Zyl-Smit RN, Richards G, Leone FT (2020). Tobacco smoking and COVID-19 infection. Lancet Respir Med, 8, 664-5.

Von Lampe K, Kurti M, Johnson J (2018). “I'm gonna get me a loosie" Understanding single cigarette purchases by adult 
smokers in a disadvantaged section of New York City. Prev Med Rep, 12,182-5.

Walt G, Gilson L (1994). Reforming the health sector in developing countries: the central role of policy analysis. Health Policy Plan, 9, 353-70.

World Health Organization (2003). WHO Framework Convention on Tobacco Control. Geneva

World Health Organization (2009). 2009 Summary Report on global progress in implementation of the WHO Framework Convention on Tobacco Control. Geneva.

World Health Organization (2018). 2018 global progress report on implementation of the WHO Framework Convention on Tobacco Control. Geneva.

Yadav A, Singh PK, Yadav N, Kaushik R, Chandan K, Chandra A, Mehrotra R (2020). Smokeless tobacco control in India: policy review and lessons for high-burden countries. $B M J$ Global Health, 5, e002367.

\section{cc) (7) (8)}

This work is licensed under a Creative Commons AttributionNon Commercial 4.0 International License. 